\title{
Relation of Diabetic Control to Development of Microvascular Complications
}

\author{
G. Tchobroutsky \\ Service de Diabétologie, Hôtel-Dieu Hospital, Paris, France
}

\begin{abstract}
Summary. This review seeks to supply the arguments which support or deny the relationship between the quality of control of blood glucose levels and the course of diabetic microangiopathy. The ideal study is impossible to do in man but most prospective studies suggest that the better the control the slower the rate of progression and severity of lesions. "Scientific" but indirect arguments from biochemical, enzymatic and functional studies have shown that insulin and/or blood glucose control reverse some early diabetic changes that are probably related to the late events. Recent studies suggest that observations on animals that have shown the beneficial effect of treatment are relevant to the problem of diabetic microvascular lesions in man. Heredity influences the development of diabetic microangiopathy in diabetics but retinal and/or glomerular lesions - which are definitely not pathognomonic for diabetes - do not appear in the absence of hyperglycaemia. Muscle capillary basement membrane thickening that seems not to be a specific abnormality was not observed by several investigators in recently diagnosed diabetics. Therefore most of the arguments that have been given to support the point of view that tight control is not justified may be rejected. The opinion of the author is that strict control of diabetes is worthwile in patients with long life expectancy and no psychological, social or cultural handicaps.
\end{abstract}

Key words: Diabetes control, microangiopathy, blood glucose, vascular complications, treatment of diabetes.

Microvascular disorders in diabetic patients are probably of multifactorial origin (1-3) including some genetic susceptibility (4-8). However several data strongly suggest that the mechanisms responsible for diabetic microangiopathy are initiated as a result of insulin deficiency and that the development of the microvascular complications of diabetes may be inhibited and/or delayed by careful control of blood glucose concentration. Some authors have questionned, however, whether the benefits of tight control are sufficiently proven to warrant the risks of hypoglycaemia $[9,10]$. They also question whether or not the microangiopathic lesions in diabetic patients could be primarily and completely determined by heredity whatever the carbohydrate tolerance [11].

This review focusses on a critique of some of these controversial points.

\section{Clinical studies}

The definite demonstration that the microvascular complications of diabetes can be prevented by the normalisation of blood glucose concentrations in man cannot be made since normoglycaemia cannot be sustained from the beginning of the disease with our current methods of treatment. The impossibility of comparing perfectly controlled and uncontrolled diabetic patients makes it possible only to study varying degrees of imperfection. Even collecting partial evidence showing in man, that the better the control, the less the rate of progression and severity of retinopathy and nephropathy is a very difficult and frustrating task. Definite criteria are lacking for the quantification of both complications and the degree of control [12]. The ideal study is impossible to do in man for practical and ethical reasons [9, 13].

The controversies during the last 50 years were partly the result of the fact that most studies were retrospective with a great deal of bias. Numerous large reviews have discussed the relationship between the degree of diabetic control and the develop- 
ment of microangiopathy $[9,14-23]$. Some were unable to show a positive effect of the quality of control $[9,14,18,23]$. In 1964 Knowles [14], after a comprehensive analysis of more than 300 reports, concluded that "information sufficient to arrive at any conclusions is not yet at hand". Almost 10 years later, Kaplan and Feinstein [18] made an analysis of the methods that were used in 149 papers. They concluded pessimistically, that a "predominantly statistical approach to therapeutic trial cannot be expected to resolve the existing scientific controversies about treatment". Bondy and Felig wrote that "... this belief must be considered a manifestation of faith rather than of scientifically proven fact" [9]. Raskin's conclusions are "There has been little convincing clinical evidence for the view that rigid control of the metabolic abnormalities will prevent the vascular complications of the disease because few diabetics have ever been rigidly controlled. However, there is no overwhelming evidence to the contrary i. e. that the vascular complications are independent of the hyperglycaemia" [23]. None-the-less most reviewers concluded that good control of blood glucose in diabetic patients in beneficial [15-17, 19-22]. Their opinion resulted essentially from the analysis of prospective studies.

Yet most of the retrospective studies, even if they have never really proven that good control was beneficial, have strongly suggested that bad control was associated with more, and severer forms of complications [24-27]. It was suggested by Constam [26] and by Caird et al. [16] that the first few years of treatment are critical: diabetics whose diabetes has been well controlled in the first few years and poorly controlled later on have fewer late complications than those with the reverse sequence. Among old studies [28-31] showing inconclusive results was that by Dolger, often cited to support the lack of any beneficial effect of good control [30]. According to Pirart and Lauvaux, however, Dolger's methods do not stand up to even superficial criticism because the criteria of control were not given $[21,32]$.

Among the twenty or so prospective studies considered valid by recent reviewers only a few have failed to show any relationship between the incidence of retinopathy and glomerulopathy and the quality of diabetic control. That done by Knowles and his colleagues in 1965 examined very poorly controlled children and adolescents [33]. As emphasised by Pirart "not having a group of well controlled subjects the authors have compared 22 cases without retinopathy to 25 cases with retinal lesions" [32]. It could be suggested that such a study, like that of Gerritzen [34] tries mainly to answer the question whether among poorly controlled diabetic patients some develop more or fewer retinal lesions. The recent UGDP report on non-fatal events claimed that attempts to normalise blood glucose in the adult onset diabetic did not alter the incidence of renal impairment, retinal changes or the other common complications of diabetes. It stated that "of course it must be recognized that few patients were found to have renal or ocular disorders over the period covered by this report, and longer periods of follow up may yield different results with respect to these vascular changes" [35].

In the study by Malone et al. [36] on children where the retinal abnormalities did not appear related to diabetic management or control, the quality of diabetes control was estimated by the presence or absence of growth failure, a rather imprecise index for refined comparisons.

Among 14 prospective studies in patients with established retinal or glomerular lesions $[21,22,35$, 37-48] 4 drew negative conclusions. The UGDP study has just been mentioned [35]. Davis showed improvement of proliferative lesions without clear evidence of any changes in diabetic management [41]. Schlesinger et al. [39] and Burditt et al. [42] were unable to show the influence of control on the rate of deterioration of established lesions. These results were discussed by Kohner and Dollery [20] who pointed out that progression of retinopathy in those two studies, despite good control, indicates the progression of one type of retinopathy to another rather than variations in severity of a particular type of lesion.

All other studies have demonstrated that good or very good control slows down the rate of deterioration of established lesions [21, 22, 37, 40, 43-48].

Kohner et al. have shown that after an average of one year of follow up, only in the groups with good or very good control did microaneurysms, haemorrhages and new vessels not worsen [43]. Miki et al. have shown that after 6 years of follow up the patients with fair and poor control had a greater frequency of worsening proteinuria than those with good control. The difference was even more marked in the patients with the highest initial fasting blood glucose [45]. Takazakura et al. have performed serial renal biopsies in 23 patients. The average interval between the first and the second biopsy was 52.6 months. Their results, despite great heterogeneity in patients, suggest that the group of diabetics in which the lesions did not worsen tended to maintain better control of blood glucose levels than the group in which the lesions were progressive [47].

The Brussels' study by Pirart and Lauvaux that followed 4,398 subjects for 25 years has shown that "the duration and severity of hyperglycaemia seem to 
be the only factors which can be definitely linked with the development, at whatever age, of diabetic triopathy and with the overall frequency of these complications. Furthermore increasing hyperglycaemia is associated with a high frequency of severe and progressive forms of diabetic retinopathy" [21, $22,32]$.

Our group in Paris decided in 1968 to assign randomly insulin-dependent patients either to long-acting insulin given once a day or to a regimen consisting of 2 or 3 injections per day. The use of multiple daily insulin injections has been advocated by several authors (in 49). In our experience this technique has in short term studies been the most effective method for the control of diabetes [49-51]. The aim of the trial was to compare the increase in the number of retinal microaneurysms (by fluorescein angiogram) in the two groups. After a mean time of 3 [48] and 4 years [52] we observed that the mean yearly increase in the number of microaneurysms and the mean survey values for fasting blood glucose concentration were lower in the multiple injection group than in the single injection group. The shifting of patients from one group to another may represent an important defect in the study $[10,23]$. In fact, patients were initially assigned either to the multiple (M) or the single (S) insulin injection group [48] and not "to the well controlled group scheduled to receive three injections of insulin per day" [10]. Some shifting occurred for only one fourth of the patients. In addition such a movement between groups could only diminish the significance of the results between the two groups and not improve it.

Thus clinical studies despite their difficulties and limits seem to support the hypothesis that good control of diabetes, at least in terms of blood glucose, is worthwile.

Are there any indirect arguments that would also justify tight control of blood sugar in some diabetic patients, at least in those with long life expectancy and no social, cultural, economical and psychological handicaps? In other words could epidemiological, pathological, biochemical and functional data help the clinician to formalise his ideas on the potential benefits of diabetes control? Dozens of abnormalities (causes or consequences of the microvasculopathy) have been described in diabetic men and animals (1-3, in 53). Among the changes that occur in the capillary wall, the perivascular tissue, the composition of blood and organ size and function, some have been proven to be reversible or preventable by conventional treatment or ideal cure of the disease.

\section{Epidemiological Studies in Man}

In 1946 the population of Oxford, Massachussetts was screened for diabetes by post-prandial blood sugar determinations. Over the subsequent 17 years O'Sullivan et al. [54] have shown that in persons who were diabetic, hypertension, electrocardiographic abnormalities, fundoscopic changes and survival rates, were all related to high initial blood sugar levels.

Jarrett and Keen have shown [55] that the percentage of patients with retinopathy at survey and 5 years later was related to the 2-hour blood sugar levels. Katsilambros reaches the same conclusions from an investigation done in Athens on 21,410 subjects [56]. The percentage of Pima Indians with proteinuria was twice as high in those with 2-hour plasma glucose levels in the range $200-299 \mathrm{mg} /$ $100 \mathrm{ml}$ than in those with values between 140 and $160 \mathrm{mg} / 100 \mathrm{ml}$. [57]. Above $200-299 \mathrm{mg} / 100 \mathrm{ml}$ increasing glucose values were not associated with an increased frequency of proteinuria. In non-insulin dependent diabetic patients we have shown [58] that retinal changes were related to the duration of diabetes and to the degree of blood sugar intolerance analysed five years previously.

\section{Clinical Microangiopathy and Pathologic Changes in Animals with Experimentally Induced Diabetes}

Since the specificity of pathological changes at the ultra-structural level has been questioned in the experimentally induced diabetic animal [10], it must first be emphasised that retinal lesions, including microaneuryms, obtained in alloxan-diabetic dogs were less marked in animals moderately well controlled with insulin given twice a day for 60 months than in dogs intentionally poorly controlled with a more conventional insulin regimen [59].

As stressed by Engerman et al. [59] the similarities between the microvascular disease in diabetic patients and dogs would suggest that these observations on animals are relevant to the problem of diabetic microvascular disease in man. It should be noted though that animals tend to develop backround rather than proliferative retinopathy.

Studies in diabetic rats, dogs and monkeys have shown that glomerular and/or retinal capillary membrane thickening undoubtedly develops after the induction of diabetes [60-71]. This includes the streptozotocin-hyperglycaemic rats studied by Mauer [71]. In chronic hyperglycaemic eels the thickness of the basement membrane of the rete capillaries is 
increased [72]. Whatever the significance [73] of such a lesion "generally held to be the sine qua non of diabetic nephropathy" $(10)$ it should be recalled that in animals with experimentally-induced diabetes, the reduction of hyperglycaemia by conventional or "ideal" treatments of the disease prevents, reduces, reverses or minimizes the formation of diabetic-like lesions in the kidney including capillary membrane thickening $[59,66,68-70,74-80]$.

\section{Biochemical and Enzymatic Changes}

There is more collagen-like glycoprotein in human diabetic glomeruli than in those of non-diabetics [81-83]. This is due to an increased synthesis [84, 85] and/or to a decreased degradation of glycoprotein $[86,87]$. Most authors claim that the increased collagen substance is not enriched in disaccharide units and that galactosyltransferase activity is not increased as compared to lysyl and prolyl-hydroxylase activities [84, 88-90]. Whatever this controversal point, it has been shown that insulin administration normalises or reduces the lysyl-hydroxylase activity in isolated glomeruli from diabetic rats [85, 91]. Fushimi and Tarui [92] showed that in streptozotocin induced diabetic rats, beta- $\mathrm{N}$-acetyl-glucose-aminidase activity was increased in the serum and decreased in the kidney after 8 weeks of diabetes. Insulin administration significantly reverses these anomalies. The authors point out that beta- $\mathrm{N}$-acetyl-glucoseaminidase is implicated in glycoprotein catabolism, principally in lysosomes, and they suggest that the diabetes-induced anomalies contribute to glycoprotein accumulation in the diabetic kidney. According to Spiro and Spiro there is an increase in the proportion of disaccharide radicals linked to the polypeptide chains in renal capillary basement membrane of diabetic men and rats [93]. These authors showed that careful and early treatment with insulin normalised the increased glucosyl-transferase activity responsible for this disaccharide accumulation in rats [93].

Thus some authors have shown a beneficial effect of insulin on the diabetes-induced renal enzymatic anomalies. However Archer and Kaye [94] have shown collagen hypersecretion by fibroblasts originating from cultured skin of diabetic humans and suggested that a genetic defect could be responsible.

\section{Functional Microangiopathy, Organ Size and Blood Composition Changes}

1) Early changes in capillary wall permeability may occur a few months or a few years after the beginning of the disease in poorly controlled diabetic subjects. Abnormal transcapillary escape rate of albumin [95], abnormal urinary albumin excretion during exercise [96] and leakage of fluorescein from the retinal vessels into the vitreous and the anterior segment of the eye have been described [97-101]. Several reports indicate that strict control of blood sugar levels reduces or abolishes these manifestations of functional microangiopathy [95-97].

Whether capillary wall thickening precedes [102], follows [103] or develops in parallel with the breakdown of the normal blood-tissue barrier is a matter of discussion. It has also been disputed whether hyperpermeability may be related to biochemical alterations in the basement membrane, such as a decrease in the cystine content of the human diabetic glomerular basement membrane [104] or an increase in disaccharide units $[81,102]$.

The main problem is to know whether these functional abnormalities should be regarded as "a forerunner of long-term diabetic complications or if the two should be thought of as independent entities" [105].

2) The early changes in renal size and function that have been described in animal and human diabetes have been shown to be reversible by very strict control of blood glucose. These reversible changes specifically include renal hypertrophy, glomerular enlargement, cellular hypertrophy, increased protein synthesis and increased GFR [105, 106].

3) Among the numerous changes that have been described in the blood in diabetes [1-3, 53, 107-113] some have been shown to be reversible or preventable or correlated to the degree of control [108-112]. Examples of this are glycosylated haemoglobin concentration [108, 111] and red cell deformability [110]. The fact that decrease of blood glucose may lead to a decrease in blood viscosity and to an increase in oxygen delivery to tissues [109] could be of paramount importance since hyperviscosity and/or hypoxia may act as triggering mechanisms for the development of capillary proliferation in the retina $[101,114]$. It has recently been pointed out that renal and retinal diabetic-like lesions have been observed in other diseases with hypoxia and/or hyperviscosity $[101,107,114,115]$. Strict control of blood glucose also normalises growth hormone secretion which may play a permissive role in the development of diabetic microangiopathy [116].

\section{Discussion}

Since scientific and definitive clinical proof in human diabetics are not (yet?) available, one of the major 
questions is whether indirect arguments taken from biochemical, enzymatic, ultrastructural and functional studies in diabetics and animals with experimental diabetes of rather short duration are relevant to this discussion. It has been questionned whether there is any direct or indirect causal relationship between early documented abnormalities and late clinical symptoms of diabetic microangiopathy or whether the two are independent manifestations or a primary underlying disease [87]. If the second proposition is true, the fact that insulin administration by ideal or conventional techniques prevents, delays or minimizes most of the events observed in early diabetes in men or animals cannot be retained to affirm that strict control of diabetes in man would be beneficial in the long term. For instance some reports [117, 118], but not all [6], have shown a positive relationship between muscle capillary basement membrane thickening and the presence of diabetic retinopathy and/or glomerulopathy. Capillary basement membrane thickening should not, however, be considered as a specific manifestation of diabetes $[73,119,120]$ and perhaps not as a cause of the late pathological changes. It may indeed be suggested from retinal and renal studies in man and animals that there is a continuous progression from early pathological and functional changes (such as the breakdown of the blood-retinal barrier) to severe and/or life threatening lesions in the eyes and kidneys. Why unpredictable neovascularization occurs only in some badly controlled patients remains obscure. As was stressed previously many different mechanisms and/or a genetic suceptibility may be involved in these different evolutionary patterns.

Because of these uncertainities some prominent scientists and physicians have questionned the validity of clinical studies and findings in animals and have asked whether the benefits of tight control have been sufficiently proven to warrant the risks of hypoglycaemia $[9,10,23,36]$. Eight groups of arguments have been given to support this point of view and these will now be discussed:

1) "Hereditary influences may play a critical part in the pathogenesis of diabetic vascular disease" [10].

Many studies have demonstrated genetic influences [4-8, 12]. In particular Pyke and Tattersall have shown that diabetes in concordant pairs of twins was more likely to be complicated by severe retinopathy than in discordant pairs [4]. But as stressed by these authors non-diabetic identical twins of diabetics have no diabetic retinopathy [4]. Studies of twins [122] and of triplets [123] have shown the lack of capillary changes in the non-diabetic subjects. Thus even if heredity influences the development of microangiopathy, diabetes is necessary for its appearence.

2) "The course of clinical microangiopathy in the individual patient is often so unpredictable that it is extremely difficult to relate it to insulin deficiency alone" $[9,10]$.

This only indicates that individuals are more or less prone to develop microangiopathy. Statistically microangiopathy develops with the duration of diabetes and is present in almost all subjects after three or four decades of the disease [16]. The individual evolution of retinal and/or glomerular lesions might depend on permissive or aggravating factors, of which only a very small number are known. Thus severe myopia, intra-ocular hypertension (in 101) and of growth hormone deficiency (in 116) seem to protect diabetics from the development of microangiopathy or at least from its severest forms. Conversely hypertension [96, 124] and increased glomerular blood flow [125] are accelerating factors. As recalled previously, heredity may also play a role. The argument according to which severe diabetics with severe metabolic decompensation have few lesions while benign diabetics (without great hyperglycaemia) would have serious ones cannot be retained. What do benign and serious diabetes really signify? Is it more serious to be affected with insulintreated diabetes, unstable, oscillating from frank (but acute) hyperglycaemia to hypoglycaemia, or with obese diabetes, unknown for 20 years, characterised by moderately but constantly elevated blood glucose levels day and night? It is therefore not possible to compare the degree of retinal and/or renal lesions to the "gravity" of the diabetes in an individual.

3) "Nodular glomerulosclerosis and retinopathy have been described in the absence of glucose intolerance" $[9,10]$.

Both lesions, even if extremely characteristic of diabetes, are not specific and not pathognomonic for diabetes. Retinal lesions have been described in diseases accompanied by hypoxia and/or hyperviscosity [in 101, in 114]. Kimmelstiel-Wilson nodules have also been found in multiple myeloma and the benign monoclonal gammopathies [126, 127, in 115].

Furthermore, if one is rigorous in one's analysis of reports of so-called cases of microangiopathy without diabetes, only two $[128,129]$ are relevant to the discussion, i.e. those which are "characteristic" of diabetes with no present nor previous hyperglycaemia. Other reports describe either lesions that are not characteristic of diabetes or subjects who are or were previously diabetic (see 21 and 130 for reviews). Some reports deal with recently discovered 
diabetes complicated by retinopathy or glomerulopathy. These can be discounted in that diabetic remissions are well known, as are the asymptomatic character of moderate chemical diabetes and the variability of glucose tolerance tests in moderate diabetes [131].

Studies on the Pima Indians where more than $40 \%$ of the subjects, 35 years old or older, are affected by the disease also carry solid arguments against the existence of diabetic nephropathy without diabetes. Kamenetzky and colleagues studied 1,848 Pima Indians. At the autopsy of 105 subjects, 43 diabetics and 62 non-diabetics, no nodular glomerulosclerosis or exudative glomerular lesion existed in the non-diabetic while the frequency in the diabetics was $55 \%$ and $44 \%$ respectively [57].

4) "Quadriceps capillary basement membrane thickening may be present at the time of diagnosis of diabetes and in so called prediabetic subjects but not in secondary diabetes [11]". "Glomerular basement membrane width in the study by Österby was actually present at $1^{1 / 2}$ years indicating that such thickening must have started even before that time [107." "Microaneurysms and/or fluorescein leakage are demonstrated in the eyes of diabetic children at a very early stage, i. e. between one and four months" [36].

Let us recall a) that several workers have shown that the capillary wall is normal at the onset of diabetes in kidney [132-134] as well as in muscle (see 120 for review); b) that the specificity of capillary basement membrane in quadriceps muscle has been questioned [120]; c) that the muscle capillary is probably not the best capillary for such studies $[135,136]$; d) that technical problems probably explain the discrepancies between laboratories [83, 120]; e) that Ruth Ósterby has carried out serial renal biopsies and claimed that the capillary wall was certainly of normal width at the first biopsy [134]; f) that fluorescein leakage is a very early phenomenon in poorlycontrolled diabetic rats [97] and man [99] which is reversible by careful treatment of the disease [97]; and finally, g) that microangiopathy has been described in secondary diabetes after a certain time both at the ultra-structural [137] and at the clinical level (see 138 for review).

Some studies in children have shown either normal basement membrane width, even with Siperstein's method [139], or a good correlation between basement membrane thickening and the degree of hyperglycaemia, its duration or the quality of control [140-142]. In a very recent review Raskin [23] emphasised that in the patients with secondary diabetes he studied, prolonged hyperglycaemia may play a role in the development of quadriceps capillary basement membrane thickening.
5) "Clinical trials remain inconclusive [10] at least because we do not have reliable biochemical measurements of control' ' [9].

This was discussed above.

6) "The relevance of animal lesions to those of man remain an open question . . Mauer et al. did not observe changes in the glomerular basement membrane material, lesions generally held to be the sine qua non of diabetic nephropathy" [10].

As discussed previously, several authors, mainly on the eastern side of the Atlantic ocean, have shown that capillary basement thickening occurs in various species with experimentally induced diabetes. Furthermore Mauer et al. have also recently described such a lesion reversible by good control [71].

7) "Biochemical changes (sorbitol accumulation and increased concentrations of glycosylated haemoglobin) have not be proven to be consistently associated with or causally related to the microangiopathic lesions of diabetes in man" [10].

Proof has been obtained that sorbitol accumulation is linked to nerve changes and cataracts (see 53 and 143 for reviews) but the postulated role of sorbitol in retinal changes still has to be tested [101]. A recent review has discussed the beneficial effects of lowering red cell oxygen affinity in diabetes in order to achieve better tissue oxygen supply [109].

8) "Frequent hypoglycaemia can be detrimental to the patient's activities. Severe hypoglycaemia has harmful effects" [10].

Of course it is important to evaluate the risks of "rigid" treatment compared with those of a "relaxed" regimen. As was emphasised [144] little is known of the risks, in particular hypoglycaemic, run by patients who force themselves to the best possible control of their hyperglycaemia with insulin. The psychological restrictions can sometimes be difficult [145] but time has shown that children and adolescents taught and educated to control their insulindependent diabetes rigidly can adapt themselves perfectly to adult life [146]. Some diabetic doctors and diabetologists, or their wives, have controlled their diabetes remarkably well as illustrated by two of them $[147,148]$.

\section{Conclusions}

The opinion of a great number of research workers and clinicians is that the microangiopathic and neuropathic changes observed in diabetes mellitus are secondary to insulin deficiency, hyperglycaemia and/or to their consequences. These facts call for 
research into the best possible means for achieving perfect control of blood glucose levels in diabetics whose life expectancy justifies this effort and whose cultural and above all psychological conditions permit it. This effort is justified even if lesions already exist since they are, to a certain degree, still responsive to good diabetic control.

Of course if one strives to achieve the best control possible day after day, there may be immense difficulties. For such goals we must use improved techniques for teaching and education; we must persuade the patient to follow his diet strictly, to divide his daily insulin administration into two or three doses (at least for the majority of patients), to be as close to ideal body weight as possible and to include physical exercise as an important aid to his treatment. Because we also try to avoid severe hypoglycaemia this task is very difficult. Sadly, if we also try to treat his hypertension (even moderate), to give him a hypocholesterolaemic diet, to treat his eyes with laser coagulation and also to stop him smoking, he will probably ignore all our advice and merely conclude that his physicians are sadists.

Acknowledgement. I am indebted to Mrs. M. M. Thiébaut for her invaluable help in the preparation of this review.

\section{References}

1. Keen, H., Jarrett, J. (Eds): Complications of Diabetes, 282 pp. London: Arnold 1975

2. McMillan, D. E., Ditzel, J. (Eds): Proceedings of a conference on diabetic microangiopathy. Diabetes 25 (Suppl. 2), 805-930 (1976)

3. Pathogenesis of diabetic microangiopathy (Leader). Br. Med. J. 1977 I, 1555-1556

4. Pyke, D. A., Tattersall, R. B.: Diabetic retinopathy in identical twins. Diabetes 22, 613-618 (1973)

5. Barbosa, J., Noreen, H., Emme, L., Goetz, F., Simmons, R., De Leiva, A., Najarian, J., Yunis, E. J.: Histocompatibility (H. L. A.) antigens and diabetic microangiopathy. Tissue Antigens 7, 233-237 (1976)

6. Becker, B., Shin, D. H., Burgess, D., Kilo, C., Piller, W. V.: His tocompatibility antigens and diabetic retinopathy. Diabetes 26, 997-999 (1977)

7. Egeberg, J., Frimodt-Moller, K., Sander, E., Svejgaard, A.: Basement membranes thickness, insulin antibodies and H. L. A. antigens in juvenile diabetics with and without proliferative retinopathy (abstract). Diabetologia 13, 391 (1977)

8. Möller, E., Persson, B., Sterky, G.: H. L. A. phenotypes and diabetic retinopathy. Diabetologia 14, 155-158 (1978)

9. Bondy, P.K., Felig, P.: Relation of diabetic control to development of vascular complications, Med. clin. North Am. 55, 889-897 (1971)

10. Siperstein, M. D., Foster, D. W., Knowles, H. C. Jr., Levine, R., Madison, L. L., Roth, J.: Control of blood glucose and diabetic vascular disease. N. Engl. J. Med. 296, 1060-1063 (1977)

11. Siperstein, M. D., Unger, R.H., Madison, L. L.: Studies of muscle capillary basement membranes in normal subjects, diabetic, and prediabetic patients. J. Clin. Invest. 47, 1973-1999 (1968)
12. Lefebvre, P., Millet, J., Luyckx, A.: Control of diabetes: an attempt to formulate policy guidelines in a department of medicine. Diabetologia 10, 201-204 (1974)

13. Tunbridge, Sir R.: Foreward. In: H. Keen, H. Jarrett (Eds): Complication of diabetes, pp. VII-IX. London: Annold 1975

14. Knowles, H. C. Jr.: The problem of the relation of the control of diabetes to the development of vascular disease. Trans. Am. Clin. Climatol. Assoc. 76, 142-147 (1964)

15. Colwell, J. A.: Effect of diabetic control on retinopathy. Diabetes 15, 497-499 (1966)

16. Caird, F. I., Pirie, A., Ramsell, T. G.: Diabetes and the eye, 230 pp. Oxford: Blackwell Scientific Publ. 1969

17. Pometta, D.: La microangiopathie diabétique. Acta Endocrinol. [suppl. 156] (Kbh.) 67, 1-144 (1971)

18. Kaplan, M. H., Feinstein, A. R.: A critique of methods in reported studies of long-term vascular complications in patients with diabetes mellitus. Diabetes 22, 160-174 (1973)

19. Stowers, J. M.: Complications in relation to diabetic control. General review. In: H. Keen, J. Jarrett (Eds): Complications of diabetes, pp. 1-5. London: Arnold 1975

20. Kohner, E. M., Dollery, C. T.: Diabetic retinopathy. In: H. Keen, J. Jarrett (Eds): Complications of diabetes, pp. 7-98. London: Arnold 1975

21. Lauvaux, J.P.: Le rôle de l'hyperglycémie chronique dans l'apparition et la développement de la triopathie diabétique: neuropathie, néphropathie, rétinopathie. (Etude clinique). Thèse Université Libre de Bruxelles 1976

22. Pirart, J.: Diabetes mellitus and its degenerative complications: a prospective study of 4.400 patients observed between 1947 and 1973 (In three parts). Diabete Metab. 3, 97-107, 173-182, 245-256 (1977)

23. Raskin, Ph.: Diabetic regulation and its relationship to microangiopathy. Metabolism 27, 235-252 (1978)

24. Jackson, R. L., Hardin, R. C., Walker, G. L., Hendricks, A. B., Kelly, H. G.: Degenerative changes in young diabetic patients in relationship to levels of control. Pediatrics $\mathbf{5}, 959$ (1950)

25. Johnsson, S.: Retinopathy and nephropathy in diabetes mellitus: comparison of the effects of two forms of treatment. Diabetes 9, 1-8 (1960)

26. Constam, G. R.: Contrôle du diabète et prévention des complications. In: Journées Diabétol. Hôtel-Dieu, pp. 313-320. Paris: Flammarion 1972

27. Francois, R., Memelle, H., Leonetti, P., Jarlot, B., Gillet, P., David, L., Tardieu, M.: Complications dégénératives après 10 ans de diabète infantile. In: Journées Diabétol. HôtelDieu, pp. 135-156. Paris: Flammarion 1976

28. Colwell, A. R.: Observed course of diabetes mellitus and inferences concerning its origin and progress. Arch. Intern. Med. 70, 523-531 (1942)

29. Mirsky, I. A.: Our challenge for the future (Editorial). Diabetes Abstracts (Cincinnati) 5, 71 (1946)

30. Dolger, H.: Clinical evaluation of vascular damage in diabetes mellitus. J. Amr. Md. As. 134, 1289-1291 (1947)

31. Muri, J.: Diabetic nephropathy and retinopathy. Acta Med. Scand. 149, 211-219 (1954)

32. Pirart, J.: Rigueur du traitement du diabète et complications rétiniennes. In: Journées Diabétol. Hôtel-Dieu, pp. 282296. Paris: Flammarion 1977

33. Knowles, H. C., Guest, G. M., Lampe, J., Kessler, M., Skillman, T. G.: The course of juvenile diabetes treated with unmeasured diet. Diabetes 14, 239-273 (1965)

34. Gerritzen, F. M.: The course of diabetic retinopathy. Diabetes 22, 122-128 (1973)

35. U. G. D. P.: A study of the effects of hypoglycemic agents on vascular complications in patients with adult-onset diabetes. VI - Supplementary report on non fatal events in patients treated with tolbutamide. Diabetes 25, 1129-1151 (1976) 
36. Malone, J. I., Van Cader, T. C., Edwards, W. C.: Diabetic vascular changes in children. Diabetes 26, 673-679 (1977)

37. Folk, M. L., Soskin, S.: The fundus oculi in diabetes mellitus. Am. J. Ophthalmol. 18, 432-437 (1935)

38. Boyd, J.D., Jackson, R. L., Allen, J.H.: Avoidance of degenerative lesions in diabetes mellitus. J. A. M. A. 118 , 694-696 (1942)

39. Schlesinger, F. G., Franken, S., Van Lange, L. T. P., Schwartz, F.: Incidence and progression of retinal and vascular lesions in long-term diabetes. Acta Med. Scand. 168, 483-488 (1960)

40. Dollery, C. T., Oakley, N. W.: Reversal of retinal vascular changes in diabetes. Diabetes 14, 121-127 (1965)

41. Davis, M. D.: Natural course of diabetic retinopathy. In: S. J. Kimura, W. M. Caygill (Eds): Vascular complications of diabetes mellitus, pp. 139-169. Saint-Louis: Mosby 1967

42. Burditt, A. F., Caird, F. I., Draper, G. J.: The natural history of diabetic retinopathy. Q. J. Med. 37, 303-317 (1968)

43. Kohner, E. M., Fraser, T. R., Joplin, G. F., Oakley, N. W.: The effect of control on diabetic retinopathy. In: M. F. Goldberg, S. L. Fine (Eds): The treatment of diabetic retinopathy, pp. 119. Washington: U.S. Public Health Service Publ. N 18901969

44. Miki, E., Fukuda, M., Kuzuya, T., Kosaka, K., Nakao, K.: Relation of the course of retinopathy to control of diabetes, age and therepeutic agents in diabetic Japanese patients. Diabetes 18, 773-780 (1969)

45. Miki, E., Kuzuya, T., Ide, T., Nakao, K.: Frequency, degree and progression with time of proteinuria in diabetic patients. Lancet 1972 I, 922-924

46. Freyler, H., Hichorlis, St., Arnfelser, H., Egerer, I.: Welche faktoren beeinflussen die progredienz der diabetischen retinopathie? Wien. Klin. Wochenschr. 86, 621-624 (1974)

47. Takazakura, E., Nakamoto, Y., Hayakawa, H., Kawai, K. Muramoto, S., Yoshida, K., Shimizu, M., Shinoda, A., Takeuchi, J.: Onset and progression of diabetic glomerulosclerosis. Diabetes 24, 1-9 (1975)

48. Job, D., Eschwege, E., Guyot-Argenton, C., Aubry, J.P., Tchobroutsky, G.: Effect of multiple daily insulin infections on the course of diabetic retinopathy. Diabetes 25, 463-469 (1976)

49. Tchobroutsky, G.: How to achieve better diabetic control? Studies with insulin three times a day. In: W. J. Malaisse, J. Pirart, J. Valance-Owen: Diabetes, pp. 667-679. Amsterdam: Excerpta Med. Int. Congr. Ser. 3121973

50. Tchobroutsky, G., Kopf, A., Eschwege, E., Assan, R.: Serial postprandial plasma insulin levels in 117 subjects with and without diabetes. Diabetes 22, 825-833 (1973)

51. Tchobroutsky, G., Lenormand, M. E., Michel, G., Assan, R.: Lack of post-prandial exercise-induced growth hormone secretion in normoglycemic insulin-treated diabetic men. Horm. Metab. Res. 6, 184-187 (1974)

52. Eschwege, E., Job, D., Guyot-Argenton, C., Aubry, J.P., Tchobroutsky, G.: Delayed progression of diabetic retinopathy by divided insulin administration: a further followup. Diabetologia (in press) (1978)

53. Alberti, K. G. M. M., Hockaday, T. D. R.: The biochemistry of the complications of diabetes mellitus. In: H. Keen, J. Jarrett (Eds): Complications of diabetes, pp. 221-264. London: Arnold 1975

54. O'Sullivan, J. B., Cosgrove, J., McCaughan, D.: Blood sugars, vascular abnormalities and survival. The Oxford study after 17 years. Postgrad. Med. J. 44 (Suppl.), 955-959 (1961)

55. Jarrett, R. J., Keen, H.: Hyperglycaemia and diabetes mellitus. Lancet $1976 \mathrm{I}, 1009-1012$
56. Katsilambros, N.: Diabetic retinopathy and blood-sugar. Lancet 1976 II, 1253

57. Kamenetzky, S. A., Bennett, P. H., Dippe, S. E., Miller, M., Lecompte, P. M.: A clinical and histologic study of diabetic nephropathy in the Pima Indians. Diabetes 23, 61-68 (1974)

58. Hautecouverture, M., Monchi, A., Tchobroutsky, G., Assan, R., Slama, G., Derot, M.: Rétinopathie diabétique et sécrétion d'hormone de croissance chez 39 diabétiques non insulino-dépendants. Nouv. Presse Med. 2, 1817-1822 (1973)

59. Engerman, R., Bloodworth, J. M. B., Jr. Nelson, S.: Relationship of microvascular disease in diabetes to metabolic control. Diabetes 26, 760-769 (1977)

60. Gibbs, G. E., Wilson, R. B., Gifford, H.: Glomerulosclerosis in the long-term alloxan diabetic monkey. Diabetes 15, 258-261 (1966)

61. Lazarow, A.: Glomerular basement membrane thickening in diabetes. In: J. Östman, R. D. G. Milner (Eds): Diabetes, pp. 301-306. Amsterdam: Excerpta Med. Int. Congr. Ser. 172 1969

62. Leuenberger, P. M., Cameron, D., Stauffacher, W., et al.: Ocular lesions in rats rendered chronically diabetic with streptozotocin. Ophthalmol. Res. 2, 189-204 (1971)

63. Bloodworth, J.M. B., Jr., Engerman, R. L., CameriniDavalos, R. A., Powers, K. L.: Variations in capillary basement membrane width produced by aging and diabetes mellitus. In: R. A. Camerini-Davalos, H. S. Cole (Eds): Early diabetes, pp. 279-295. New-York, London: Academic Press 1973

64. Cameron, D. P., Amherdt, M., Leuenberger, P., Orci, L., Stauffacher, W.: Microvascular alterations in chronically streptozotocin-diabetic rats. In: R. A. Camerini-Davalos, H. S. Cole (Eds): Early diabetes. pp. 257-269. New York, London: Academic Press 1973

65. Duhault, J., Boulanger, M., Lebon, F., Beert, L.: La microangiopathie diabétique expérimentale. Nouv. Presse Med. 2, 3013-3017 (1973)

66. Hägg, E.: On the pathogenesis of glomerular lesions in the alloxan diabetic rat. Acta Med. Scand. (Suppl.) 558, 1-31 (1974)

67. Stout, C., Kennedy, A., Folse, D., Beathard, G., Granholm, N., Padula, R., Williams, G. R., Whorton, E., Davis, E., Kimmelstiel, P.: Glomerulosclerosis in "secondary" diabetes in baboons (abstract). Diabetes 25 (Suppl. 1), 349 (1976)

68. Fox, C. J., Darby, S. C., Ireland, J. T., Sönksen, P. H.: Blood glucose control and glomerular capillary basement membrane thickening in experimental diabetes. Br. Med. J. 1977 I, 605-607

69. Rasch, R.: The effect of diabetic control on kidney weight, glomerular volume and glomerular basement membrane thickness (abstract). Diabetologia 13, 426 (1977)

70. Slater, D. N., Mangnall, Y., Smythe, A., Ward, A. M., Fox, M.: Neonatal islet cell transplantation in the diabetic rat: effect on the renal complications. Br. J. Pathol. 124, 117-124 (1978)

71. Mauer, S. M., Steffes, M. W., Brown, D. M.: Animal models of diabetic nephropathy. In: M. Maxwell (Ed): Advances in nephrology. Chicago: Year Book Med. 1978 (in press)

72. Bendayan, M., Sandborne, E., Rasio, E.: Concurrent studies on the morphology, the permeability and the metabolism of a blood capillary preparation (abstract). Diabetologia 10, 358 (1974)

73. McMillan, D. E., Mauer, S. M.: Diabetes and vascular discase. N. Engl. J. Med. 297, 392-393 (1977)

74. Federlin, K., Bretzel, R.G., Schmidtchen, U.: Islet transplantation in experimental diabetes of rat. 5 - Regression of 
glomerular lesions in diabetic rats after intraportal transplantation of isogeneic islets. Preliminary results. Horm. Metab. Res. 8, 404-406 (1976)

75. Bloodworth, J. M. B., Jr. Engerman, R. L.: Diabetic microangiopathy in the experimentally-diabetic dog and its prevention by careful control with insulin (abstract). Diabetes 22 (suppl. 1), 290 (1973)

76. Gray, B. N., Watkins, E.: Prevention of vascular complications of diabetes by pancreatic islet transplantation. Arch. Surg. 111, 254-257 (1976)

77. Lee, C. S., Mauer, S. M., Brown, D. M., Sutherland, D. E. R., Michael, A. F., Najarian, J. S.: Renal transplantation in diabetes mellitus in rats. J. Exp. Med. 139, 793-800 (1974)

78. Mauer, S. M., Sutherland, D. E. R., Steffes, M. W., Leonard, R. J., Najarian, J. S., Michael, A. F., Brown, D. M.: Pancreatic islet transplantation. Effects on the glomerular lesions of experimental diabetes in the rat. Diabetes 23, 748-753 (1974)

79. Orloff, M. J., Lee, S., Charters, A. C., III. Grambort, D. E., Storck, L. G., Knox, D.: Long term studies of pancreas transplantation in experimental diabetes mellitus. Ann. Surg. 182, 198-206 (1975)

80. Weil, R., Nozawa, M., Koss, M., Weber, C., Reemtsma, K. B., McIntosh, R.: Pancreatic transplantation in diabetic rats: renal function, morphology, ultrastructure and immunohistology. Surgery 78, 142-148 (1975)

81. Beisswenger, P. J., Spiro, R. G.: Studies on the human glomerular basement membrane. Composition, nature of the carbohydrate units and chemical changes in diabetes mellitus. Diabetes 22, 180-193 (1973)

82. Klein, L., Butcher, D. L., Sidilovsky, O., Kikkawa, R., Miller, M.: Quantification of collagen in renal glomeruli isolated from human non diabetic and diabetic kidneys. Diabetes $\mathbf{2 4}$, 1057-1065 (1975)

83. Reddi, A. S.: Diabetic microangiopathy. I - Current status of the chemistry and metabolism of the glomerular basement membrane. Metabolism 27, 107-124 (1978)

84. Ristelli, J., Koivisto, V. A., Akerblom, H. K., Kivirikko, K. I.: Intracellular enzymes of collagen biosynthesis in rat kidney in stretozotocin diabetes. Diabetes 25, 1066-1070 (1976)

85. Cohen, M. P., Khalifa, A.: Renal glomerular collagen synthesis in streptozotocin diabetes. Reversal of increased basement membrane synthesis with insulin therapy. Biochim. Biophys. Acta (in press)

86. Brownlee, M.: $\alpha$ 2-macroglobulin and reduced basementmembrane degradation in diabetes. Lancet 1976 I, 779-780

87. Lazarow, A., Speidel, E.: The chemical composition of the glomerular basement membrane and its relationship to the production of diabetic complications. In: M.D. Siperstein, A. R. Colwell, Sr., K. Meyer (Eds): Small Blood Vessel Involvement in Diabetes Mellitus, p. 127. Washington: American Institute of Biological Sciences 1964

88. Westberg, N. G., Michael, A. F.: Human glomerular basement membrane: chemical composition in diabetes mellitus. Acta Med. Scand. 194, 39-47 (1973)

89. Kefalides, N. A.: Biochemical properties of human glomerular basement membrane in normal and diabetic kidneys. J. Clin. Invest. 53, 403-407 (1974)

90. Duhault, J., Lonchampt, M.: Glucosyl transferase activity and diabetic microangiopathy. Biomedicine 27, 127-131 (1977)

91. Cohen, M. P., Khalifa, A.: Effect of diabetes and insulin on rat renal glomerular protocollagen hydroxylase activities. Biochim. Biophys. Acta 496, 88-94 (1977)

92. Fushimi, H., Tarui, S.: Kidney and serum beta-N-acetyl- glucosaminidase activities in streptozotocin diabetic rats and their responses to insulin and glucagon. J. Biochem. (Tokyo) 76, 225-227 (1974)

93. Spiro, R. G., Spiro, M. J.: Effect of diabetes on the biosynthesis of the renal glomerular basement membrane. Diabetes 20, 641-648 (1971)

94. Archer, J., Kaye, R.: Cultured skin fibroblasts and juvenile diabetes: senescence and collagen synthesis (abstract). Diabetes 26 (Suppl. 1), 361 (1977)

95. Parving, H.H.: Increased microvascular permeability to plasma proteins in short-and long-term juvenile diabetics. Diabetes 25 (Suppl. 2), 884-889 (1976)

96. Mogensen, C. E.: Renal function changes in diabetes. Diabetes 25 (Suppl. 2), 872-879 (1976)

97. Waltman, S. R., Oestrich, C. A., Hanish, S., et al.: Blood retinal barrier in experimental diabetes. Presented at the spring meeting of the Ass. for Research in Vision and Ophthalmology, Sarasota (Florida), April 1977

98. Cunha-Vaz, J. G., Faria de Abreu, J. R., Campos, A. J.: Early breakdown of the blood-retinal barrier in diabetes. $\mathrm{Br}$. J. Ophthalmol. 59, 649-656 (1975)

99. Dorchy, H., Toussaint, D., Devroede, M., Ernould, C.: Angiofluorescein studies in infantile diabetic retinopathy. Intern. Study Group Diabetes in Children and Adolescents 10-11 (1977)

100. Waltman, S. R., Oestrich, C., Krupin, T., Hanish, S., Ratzan, S., Santiago, J., Kilo, Ch.: Quantitative vitreous fluorophotometry. A sensitive technique for measuring early breakdown of the blood-retinal barrier in young diabetic patients. Diabetes 27, 85-87 (1978)

101. Palmberg, P. F.: Diabetic retinopathy. Diabetes 26, 703-709 (1977)

102. Spiro, R. G.: Search for a biochemical basis of diabetic microangiopathy. Diabetologia 12, 1-14 (1976)

103. Williamson, J. R., Kilo, C.: Basement-membrane thickening and diabetic microangiopathy. Diabetes 25 (Suppl. 2), 925-927 (1976)

104. Westberg, N.G.: Biochemical alterations of the human glomerular basement membrane in diabetes. Diabetes $\mathbf{2 5}$ (Suppl. 2), 920-924 (1976)

105. Gundersen, H. J. G., Mogensen, C. E., Seyer-Hansen, K., Østerby, R., Lundbaek, K.: Early and late changes in the diabetic kidney. In: M. Maxwell (Ed): Advances in nephrology. Chicago: Year Book Med. Publ. 1978 (in press)

106. Parving, H. H., Noer, I., Deckert, T., Evrin, P. E., Nielsen, S. L., Lyngsøe, J., Mogensen, C. E., Rørth, M., Svendsen, P. Aa., Trap-Jensen, J., Lassen, N. A.: The effect of metabolic regulation on microvascular permeability to small and large molecules in short-term juvenile diabetes. Diabetologia 12, 161-166 (1976)

107. Mc Millan, D. E.: Plasma protein changes, blood viscosity and diabetic microangiopathy. Diabetes 25 (Suppl. 2), 858-864 (1976)

108. Koenig, R. J., Peterson, C. M., Kilo, C., Cerami, A., Williamson, J. R.: Hemoglobin Alc as indicator of the degree of glucose intolerance in diabetes. Diabetes 25, 230-232 (1976)

109. Ditzel, J.: Oxygen transport impairment in diabetes. Diabetes 25 (Suppl. 2), 832-838 (1976)

110. Schmid-Schönbein, H., Volger, E.: Red-cell aggregation and red-cell deformability in diabetes. Diabetes 25 (Suppl. 2), 897-902 (1976)

111. Lanoe, R., Thibult, N., Eschwege, E., Soria, J., Soria, C., Tchobroutsky, G.: Glycosylated haemoglobin concentrations and clinitest results in insulin dependent diabetes. Lancet 1977 II, 1156-1157

112. Preston, F. E., Ward, J. D., Marcola, B. H., Porter, N. R., 
Timperley, W. R., O'Malley, B. C.: Elevated $\beta$-thromboglobulin levels and circulating platelet aggregates in diabetic microangiopathy. Lancet 1978 I, 238-239

113. Platelet, Beta-thromboglobulin and diabetes mellitus. Lancet 1978 I, 250-251

114. Barnes, A. J., Locke, P., Scudder, P. R., Dormandy, T. L., Dormandy, J. A., Slack, J.: Is hyperviscosity a treatable component of diabetic microcirculatory disease? Lancet 1977 II, 789-781

115. Beaufils, M., Morel-Maroger, L.: Pathogenesis of renal disease in monoclonal gammopathies: current concepts. Nephron 20, 125-131 (1978)

116. Lundbaek, K.: Growth hormone's role in diabetic microangiopathy. Diabetes 25 (Suppl. 2), 845-849 (1976)

117. Kilo, C., Vogler, N., Williamson, J. R.: Muscle capillary basement membrane changes related to aging and to diabetes mellitus. Diabetes 21, 881-905 (1972)

118. Yodaiken, R. E., Menefee, M., Seftel, H.C., Dip, M. B., Kew, M. C., Mc Claren, M. J.: Capillaries of South African diabetics. IV - Relation to retinopathy. Diabetes 24, 286-290 (1975)

119. Vracko, R., Strandness, D. E.: Basal lamina of abdominal skeletal muscle capillaries in diabetics and non diabetics. Circulation 41, 271-283 (1970)

120. Williamson, J. R., Kilo, C.: Current status of capillary basement-membrane disease in diabetes mellitus. Diabetes 26, 65-75 (1977)

121. Larkins, R. G., Martin, F. I. R., Tait, B. D.: HLA patterns and diabetic retinopathy. Br. Med. J. 1978 I, 1111

122. Karam, J. H., Rosenthal, M., O’Donnel, J. J., Tsalikian, E., Lorenzi, M., Gerich, J. E., Siperstein, M. D., Forsham, P. H.: Discordance of diabetic microangiopathy in identical twins. Diabetes 25, 24-28 (1976)

123. Ganda, O.P., Soeldner, J. S., Gleason, R. E., Smit, T. M. Kilo, C., Williamson, T. R.: Monozygotic triplets with discordance for diabetes mellitus and diabetic microangiopathy. Diabetes 26, 469-479 (1977)

124. Mauer, S. M., Steffes, M. W., Azar, S., Kupcho-Sandberg, S., Brown, D. M.: The effects of goldblatt hypertension on the development of glomerular lesions of diabetes mellitus in the rat. (in press). Cited by Mauer [71]

125. Steffes, M.W., Brown, D. M., Mauer, S. M.: Diabetic glomerulopathy following unilateral nephrectomy in rat. Diabetes 27, 35-41 (1978)

126. Olsen, S.: Mesangial thickening and nodular glomerular sclerosis in diabetes mellitus and other diseases. Acta Pathol. Microbiol. Scand. [A] 80, (Suppl. 233), 203-216 (1972)

127. Schubert, G. E., Adam, A.: Glomerular nodules and longspacing collagen in kidneys of patient with multiple myeloma. J. Clin. Pathol. 27, 800-805 (1974)

128. Harrington, A. R., Hare, H. G., Chambers, W. M., Valmin, H.: Nodular glomerulosclerosis suspected during life in a patient without demonstrable diabetes mellitus. N. Engl. J. Med. 275, 206-208 (1966)

129. Strauss, F. G., Argy, W.P., Jr., Schreiner, G. E.: Diabetic glomerulosclerosis in the absence of glucose intolerance. Ann. Intern. Med. 75, 239-242 (1971)

130. Tchobroutsky, G.: Can one prevent and how to treat diabetic nephropathy. In: M. Maxwell (Ed): Advances in nephrology. Chicago: Year Book Med. Publ. 1978 (in press)

131. Fajans, S. S., Taylor, C. I., Floyd, J. C., Jr., Conn, J. W.: Some aspects of the natural history of diabetes mellitus. In: W. J. Malaisse, J. Pirart, J. Vallance-Owen (Eds): Diabetes, pp. 329-340. Amsterdam: Excerpta Med. Int. Congr. Ser. 1974
132. Lazarow, A.: Glomerular basement membrane thickening in diabetes. In: J. Östman, R. D. G. Milner (Eds): Diabetes, pp. 301-306. Amsterdam: Excerpta Med. Int. Congr. Ser. 1969

133. Ireland, J.T.: Diagnostic criteria in the assessment of glomerular capillary basement membrane lesions in newly diagnosed juvenile diabetics. In: R. A. Camerini Davalos, H. S. Cole (Eds): Early Diabetes, pp. 273-278. New York: Academic Press 1970

134. Osterby, R.: Course of diabetic glomerulopathy. In: K. Lundbaek, H. Keen (Eds), Blood vessel disease in diabetes mellitus, Acta Diabetol. Lat. 8 (Suppl. 1), 179-191 (1971)

135. Pardo, V., Perez-Stable, E., Alzamora, D. B., Cleveland, W. W.: Incidence and significance of muscle capillary basal lamina thickness in juvenile diabetes. Am. J. Pathol. 68, 67-78 (1972)

136. Cameron, J. S., Ireland, J. T., Watkins, P. J.: The kidney and renal tract. In: H. Keen, J. Jarrett (Eds), Complications of diabetes, pp. 99-150. London: Arnold 1975

137. Ireland, J. T., Patnaik, B. K., Duncan, L. J. P.: Glomerular ultrastructure in secondary diabetics and normal subjects. Diabetes 16, 628-642 (1967)

138. Lyra de Lacerda, S., Bernades, P., Lenriot, J. P., Feingold, J., Tchobroutsky, G.: Les facteurs génétiques interviennent-ils dans la genèse du diabète sucré des pancréatopathies chroniques? In: Journées Diabétol. Hôtel-Dieu, pp. 45-52. Paris: Flammarion 1978

139. Raskin, P., Marks, J. F., Burns, M., Jr., Plumer, M.E., Siperstein, M. D.: Capillary basement membrane width in diabetic children. Am. J. Med. 58, 365-372 (1975)

140. Jackson, R., Guthrie, R., Esterly, J., Bilginturan, N., James, R., Yeast, J., Saathof, J., Guthrie, D.: Muscle capillary basement membrane changes in normal and diabetic children (abstract). Diabetes 24 (Suppl. 2), 400 (1975)

141. Sheikholislam, B. M., Irias, J. J., Lin, H. J., Lowrey, G. H., Stephenson, S. R., Peterson, G. E., Devereux, D. F., Volk, T. L.: Carbohydrate metabolism and capillary basementmembrane thickness in children. I - Cross-sectional studies. Diabetes 25, 650-660 (1976)

142. Sheikholislam, B. M., Irias, J. J., Lowrey, G. H., Lin, H. J.: Carbohydrate metabolism and capillary basement-membrane thickness in children. II - Longitudinal studies. Diabetes 25, 661-666 (1976)

143. Thomas, P. K., Ward, J. D.: Diabetic neuropathy. In: H. Keen, J. Jarrett (Eds): Complications of diabetes, pp. 151-177. London: Arnold 1975

144. Ingelfinger, F. J.: Debates on diabetes. N. Engl. J. Med. 296, 1228-1229 (1977)

145. Knibbs, S., Jackson, J. G. L.: Social and emotional complications of diabetes. In: H. Keen, J. Jarrett (Eds): Complications of diabetes, pp. 265-277. London: Arnold 1975

146. Guthrie, R. A.: Young people and diabetes-control makes sense. Diabetes Forecast 30, 18-21 (1977)

147. Shepherd, G. R.: Diabetes mellitus of juvenile onset with 40 years'survival and no gross damage. Arch. Intern. Med. 128, 284-290 (1971)

148. Krall, L. P.: For Peter Forsham M. D. - The accent is on living. Diabetes Forecast 30, 14-16 (1977)

Received: May 22, 1978

Dr. G. Tchobroutsky

Service de Diabétologie

Hôtel-Dieu Hospital

F-75181 Paris Cedex 04

France 